\title{
Wat werkt bij de bevordering van arbeidsparticipatie van statushouders
}

Deze infographic is samengesteld met gegevens uit het dossier Wat werkt bij de bevordering van arbeidsparticipatie van statushouders dat is ontwikkeld door Kennisplatform Integratie \& Samenleving (KIS). In het dossier zijn gegevens uit wetenschappelijk onderzoek verzameld. Kijk op www.movisie.nl/watwerktbij voor de volledige infographic.

MOVISIE kennis en aanpak van NWII

Combineren taalles met praktijkervaring: taal vergroot kans op werk werk vergroot kennis taal.

Direct starten met taalonderwijs bij

binnenkomst

vestigingsland.

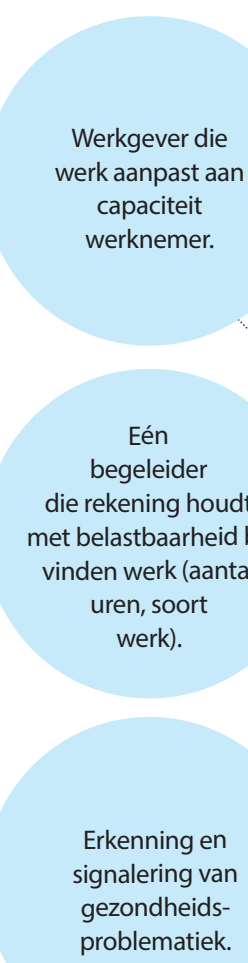

Taallessen op hoger niveau beschikbaar voor hoger opgeleide statushouders.

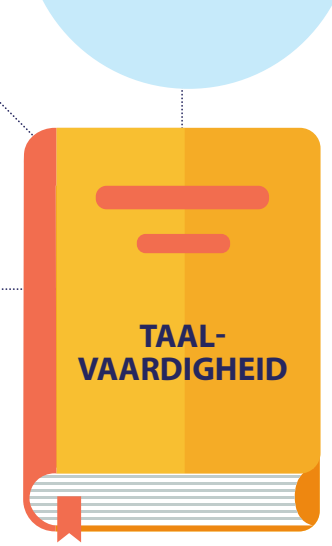

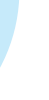
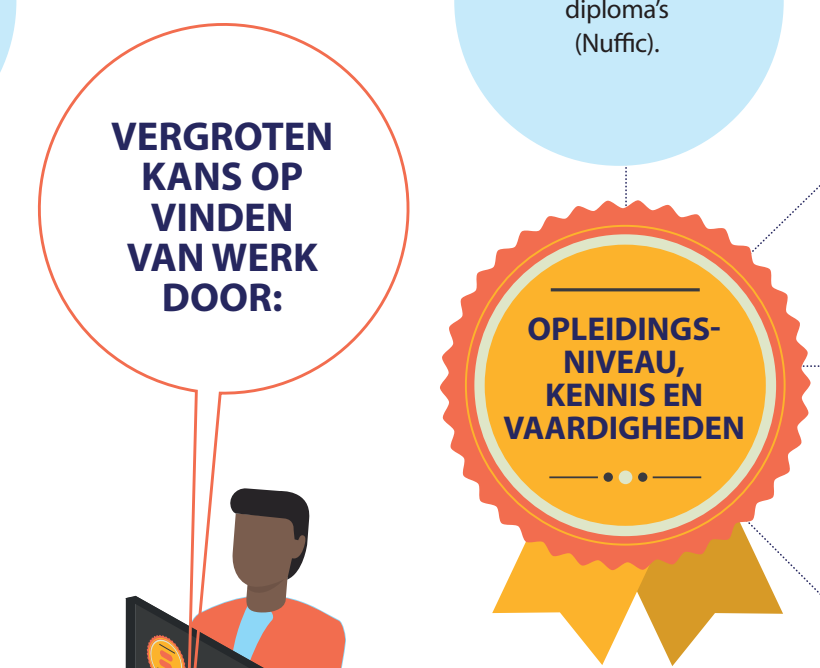
diploma's (Nuffic).

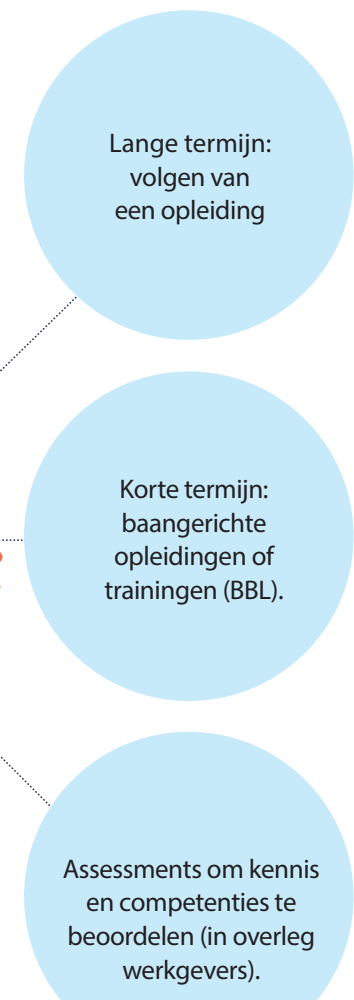

Mogelijkheden om sociaal netwerk te verbreden.

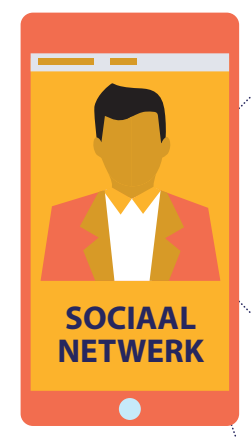

Trainingen, zoeken presentatievaardigheden.

Inzet mentor of coach.

Werkgever vooraf informeren over belastbaarheid en vaardigheden statushouder.
Bemiddelaar is essentieel (contact met werkgever en werkzoekende). 